\title{
Factors Related to Blood Glucose levels among type II Diabetes Mellitus Patients ( $A$ Cross-sectional study in Kedungmundu Public Health Center, semarang) by Lintang Saraswati
}

Submission date: 28-Sep-2018 08:25PM (UTC+0700)

Submission ID: 1010061441

File name: Lampiran_C1-26_Artikel_utk_turnitin.pdf (478.66K)

Word count: 2378

Character count: 11908 


\title{
13 \\ Factors Related to Blood Glucose Levels among Type II Diabetes Mellitus Patients (A Cross-Sectional Study in Kedungmundu Public Health Center, Semarang)
}

\author{
Lintang Dian Saraswati ${ }^{1}$, Anto Budiharjo ${ }^{2}$, Putri Septyarini ${ }^{3}$, Praba Ginandjar ${ }^{4}$ \\ 'Department Epidemiology and Tropical Diseases, Faculty of Public Health, 'Department of Biology, Faculty \\ of Sciences and Mathematics, ${ }^{3}$ Master Program of Epidemiology, School of Postgraduate Studies, ${ }^{4}$ Department \\ Epidemiology and Tropical Diseases, Faculty of Public Health, Diponegoro University, Semarang, Indonesia
}

\begin{abstract}
Diabetes mellitus (DM) is a disease that require continuous treatment and management in order to prevent complication. The aim was to determine DM in adult outpatient and to analyze correlation between some factors with blood glucose level in diabetes mellitus patient. The method was observational with crosssectional study design. The amount of sample was 200 subject, all adult outpatient of Kedungmundu Health Center from May-August 2018 and willing to be tested and interviewed, selected by total sampling. Data were collected through interview with questionnaire and measurement of fasting blood sugar. We conduct univariate, bivariate and multivariate analysis. The result of research showed that 173 out of 200 respondents were diabetes mellitus, $60 \%$ respondents had an uncontrollable blood glucose level. Furthermore multivariate analysis showed that there was correlation between duration of diabetes, medication adherence, physical exercise level, type of physical exercise, duration of physical exercise and family supports with blood glucose level. It is suggested to give education not just for diabetic patients but also to the closest family of diabetes mellitus patient. DM patients suggested to do regular physical exercise with duration more than 90 minutes/weeks and increase the medication adherence to prevent the complication of the disease.
\end{abstract}

Keywords: diabetes mellitus, medication adherence, physical activity, blood glucose level

\section{INTRODUCTION}

Diabetes Mellitus (DM) is a chronic disease that occurs when the pancreas does not produce enough insulin or alternativel 12 when the body cannot use the insulin effectively. Type 2 diabetes mellitus is the effect of impaired insulin secretion. ${ }^{.}$Results of Basic Health Research, Ministry of Health of the Republic of Indonesia in 2007 stated that $6.9 \%$ of the Indonesian population suffered from Diabetes Mellitus, $69.6 \%$ of which were undiagnosed. While in 2013 there were

\section{Corresponding author :}

Lintang Dian Saraswati, Department Epidemiology and Tropical Diseases, Public Health Faculty, Diponegoro University, Jl. Prof. Sudarto, SH,Tembalang, Semarang, 50275.

Email: lintang.saraswati@live.undip.ac.id
$5.7 \%$ of patients but the increase of undiagnosed DM patients become $73.7 \%$ were happened. ${ }^{2}$ The prevalence of Type 2 DM in Semarang was $27 \% .{ }^{3}$ Kedungmundu Health Center is one of the health centers with the largest DM cases in the city of Semarang with a proportion of cases of $30.3 \%$ in 2015 .

The proportion of DM in Kedungmundu Health Center is higher than the proportion of cases of DM in the city of Semarang. DM is characterized as chronic hyperglycemia which is drag the patient to the vasculature injury. ${ }^{4}$ Management of blood glucose level is known to play 11 pportant role in preventing diabetes complications. ${ }^{5}$ Although the management of blood glucose levels has proven to be a factor that prevents complications of DM patients, previous studies reported that $60 \%$ of DM patients had poor blood glucose control. ${ }^{6}$ This research wants to know the contributing factors related to the management of blood glucose 
levels among DM Type 2 patients in Kedungmundu Health Center, Semarang.

\section{METHOD}

This research is a quantitative research with observational analytic type. The study design used in this study is a cross sectional study design. This research was conducted from May to August 2017 in the work area of Kedungmundu Health Center Semarang. The population in this study were all outpatients who visited the Kedungmundu Health Center from May to August 2018 and willing to be tested and interviewed as much as 200 subjects. The sampling technique used is total sampling technique. Then, subject with positive DM result for blood glucose screening interviewed using questionnaire (173 subject). Variable dependent consist of the blood glucose levels, while independent variable consist of the duration suffered diabetes, obesity, physical activity, frequency of physical exercise, dietary compliance, medication adherence, family support, and motivation levels. The data obtained were then analyzed univariate, bivariate and multivariate to know the contributing factors of blood glucose levels.

\section{RESULTS AND DISCUSSIONS}

From 200 person who visited Kedungmundu Health Center, 173 of them diagnosed as DM Type 2. The results showed that most of the respondents are female (76.9\%), aged 50-64 ye 9 s (64.7\%), working as housewife $(66.5 \%)$. This result is in line with the study conducted by Ruhembe et al in Tanzania, found most of the respondents are female $(60.8 \%)$, not working (38.93\%), aged $30-40$ years $(43.84 \%)^{7}$

Table.1 The characteristic of the respondents $(n=173)$

\begin{tabular}{|l|l|l|}
\hline Characteristic respondents & f & $\%$ \\
\hline Sex & & \\
\hline Female & 133 & 76.9 \\
\hline Male & 40 & 23.1 \\
\hline Age & & \\
\hline 36-49 years & 29 & 16.8 \\
\hline 50-64 years & 112 & 64.7 \\
\hline$>64$ years & 32 & 18.5 \\
\hline Occupation & & \\
\hline Retired & 21 & 12.1 \\
\hline Housewife & 115 & 66.5 \\
\hline Non-government employee & 10 & 5.8 \\
\hline Entrepreneur & 11 & 6.4 \\
\hline Labors & 5 & 2.9 \\
\hline Others & 11 & 6.4 \\
\hline
\end{tabular}

Our study revealed that most of the respondents have uncontrolled blood glucose level (60.1\%), more than half of them are diagnosed DM for less than 2 years ago $(50.3 \%)$, obese $(51.4 \%)$, and take the medication regularly $(50.9 \%)$. There are $70.5 \%$ of them have mild psychical activities, usually they are walking (43.4\%) with the frequency within 1 weeks $<90$ minutes $(62.4 \%)$. They have high motivation levels $(54.3 \%)$, more than half of them get family support (54.3\%), and about three quarters of them (77.5\%) are not adhere to do healthy DM diet.

This result is line with previous study conducted in Saudi Arabia found that $80.6 \%$ respondents are not following the meal plan, $69.1 \%$ high adherence in taking medication, $58 \%$ high adherence to do exercise. ${ }^{8}$ While study conducted in Brazil found that $55.8 \%$ respondents don't get insulin treatment, with irregular dietary control (74.4\%), and $82.2 \%$ of them are don't have dietary guidance. $^{9}$

Table.2 The distribution of variables in DM patient $(n=173)$

\begin{tabular}{|c|c|c|}
\hline Characteristic respondents & $\mathrm{f}$ & $\%$ \\
\hline \multicolumn{3}{|l|}{ 1. Blood glucose levels } \\
\hline Controlled & 69 & 39.9 \\
\hline Uncontrolled & 104 & 60.1 \\
\hline \multicolumn{3}{|l|}{ 2. Duration of suffered DM } \\
\hline$>2$ years & 86 & 49.7 \\
\hline$<=2$ years & 87 & 50.3 \\
\hline \multicolumn{3}{|l|}{ 3. Obesity status } \\
\hline Obese & 89 & 51.4 \\
\hline Overweight & 37 & 21.4 \\
\hline Normal & 47 & 27.2 \\
\hline \multicolumn{3}{|l|}{ 4. Medication adherence } \\
\hline Adhere & 88 & 50.9 \\
\hline Not adhere & 86 & 49.1 \\
\hline \multicolumn{3}{|l|}{ 5. Physical activities level } \\
\hline Low & 30 & 17.3 \\
\hline Mild & 122 & 70.5 \\
\hline High & 21 & 12.1 \\
\hline \multicolumn{3}{|l|}{ 6. Type of physical activities } \\
\hline Inactivity & 57 & 32.9 \\
\hline Walking & 75 & 43.4 \\
\hline Gymnastic & 34 & 19.7 \\
\hline Jogging & 2 & 1.2 \\
\hline Cycling & 5 & 2.9 \\
\hline \multicolumn{3}{|l|}{$\begin{array}{l}\text { 7. Frequency of physical } \\
\text { activities 1 week }\end{array}$} \\
\hline$<90$ minutes/ week & 108 & 62.4 \\
\hline$\geq 90$ minutes / week & 65 & 37.6 \\
\hline 8. Family support & & \\
\hline
\end{tabular}


Cont... Table. 2 The distribution of variables in DM patient $(n=173)$

\begin{tabular}{|l|c|c|}
\hline Supported & 92 & 53.2 \\
\hline Not supported & 81 & 46.8 \\
\hline 9. Motivation levels & & \\
\hline Low & 79 & 45.7 \\
\hline High & 94 & 54.3 \\
\hline 10. The adherence of diet & & \\
\hline Adhere & 39 & 22.5 \\
\hline Not Adhere & 134 & 77.5 \\
\hline
\end{tabular}

From table 3 revealed that the duration of DM, medication adherence, physical activities level, type of physical activities, frequency of physical activities in one week, and the family support were significantly associated with the levels of blood glucose among type 2 DM patients ( $\mathrm{p}$ value $<0.05$ ).

Table 3. The contributing factors associated with blood glucose levels among patients type $2 \mathrm{DM}$ in Kedungmundu Health Center

\begin{tabular}{|c|c|c|c|c|c|}
\hline \multirow{3}{*}{ Variables } & \multicolumn{4}{|c|}{ Blood glucose status } & \multirow{3}{*}{$\begin{array}{l}P \\
\text { value }^{\star}\end{array}$} \\
\hline & \multicolumn{2}{|c|}{ Uncontrolled } & \multicolumn{2}{|c|}{ Controlled } & \\
\hline & $\mathbf{f}$ & $\%$ & f & $\%$ & \\
\hline \multicolumn{6}{|c|}{$\begin{array}{l}\text { Duration of } \\
\text { suffered DM }\end{array}$} \\
\hline$>2$ years & 53 & 61.6 & 33 & 38.4 & 0.030 \\
\hline$<=2$ years & 51 & 60.1 & 36 & 41.4 & \\
\hline \multicolumn{6}{|c|}{ Obesity status } \\
\hline Obese & 44 & 49.4 & 45 & 50.6 & 0.252 \\
\hline Overweight & 34 & 91.9 & 3 & 8.1 & \\
\hline Normal & 26 & 55.3 & 21 & 44.7 & \\
\hline \multicolumn{6}{|l|}{$\begin{array}{l}\text { Medication } \\
\text { adherence }\end{array}$} \\
\hline Adhere & 68 & 52.7 & 61 & 47.3 & 0.000 \\
\hline Not adhere & 36 & 81.8 & 8 & 18.2 & \\
\hline \multicolumn{6}{|c|}{$\begin{array}{l}\text { Physical activities } \\
\text { level }\end{array}$} \\
\hline Low & 23 & 76.3 & 7 & 23.3 & 0.000 \\
\hline Mild & 78 & 63.9 & 44 & 36.1 & \\
\hline High & 3 & 14.3 & 18 & 85.7 & \\
\hline \multicolumn{6}{|c|}{$\begin{array}{l}\text { Type of physical } \\
\text { activities }\end{array}$} \\
\hline Inactivity & 29 & 50.9 & 28 & 49.1 & 0.007 \\
\hline Walking & 56 & 74.7 & 19 & 25.3 & \\
\hline Gymnastic & 14 & 41.2 & 20 & 58.8 & \\
\hline Jogging & 0 & 0.0 & 2 & 100 & \\
\hline Cycling & 5 & 100 & 0 & 0.0 & \\
\hline
\end{tabular}

Cont.. Table 3. The contributing factors associated with blood glucose levels among patients type 2 DM in Kedungmundu Health Center

\begin{tabular}{|l|l|l|l|l|l|}
\hline $\begin{array}{l}\text { Duration of } \\
\text { physical activities } \\
1 \text { week }\end{array}$ & & & & & \\
\hline$<90$ minutes/ week & 62 & 57.4 & 46 & 42.6 & 0.003 \\
\hline $\begin{array}{l}\geq 90 \text { minutes / } \\
\text { week }\end{array}$ & 42 & 64.6 & 23 & 35.4 & \\
\hline Family support & & & & & \\
\hline Supported & 31 & 33.7 & 61 & 66.3 & 0.000 \\
\hline Not supported & 73 & 90.1 & 8 & 9.9 & \\
\hline $\begin{array}{l}\text { The adherence of } \\
\text { diet }\end{array}$ & & & & & \\
\hline Adhere & 79 & 45.7 & 55 & 31.8 & 0.157 \\
\hline Not adhere & 25 & 14.5 & 14 & 8.1 & \\
\hline Motivation levels & & & & & \\
\hline Low & 48 & 60.8 & 31 & 39.2 & 0.780 \\
\hline High & 56 & 59.6 & 38 & 40.4 & \\
\hline
\end{tabular}

This results are similar with the previfo study, found that the duration of diabetes is strongly associated with the glycemic control in patients living with type 2 DM. $^{10}$ Another study conducted by Rasheed et al revealed regular exercise is significantly related to the decrease of blood glucose level into normal range among DM patients. ${ }^{11}$ Type of aerobic exercise such as cycling, walking and jogging affect the blood glucose, it tends to decline and increase the sensitivity of insulin. ${ }^{12}$ The intensity and duration of physical exercises 7 ay important role on the glycemic control through glucose production shifts from hepatic glycogenolysis to enhanced gluconeogenesis as duration increase. ${ }^{13}$ Support family is also related with glycemic control for people living with diabetes. This result is similar to those reported by Strizich who found that people with low family support are likely to have uncontrolled diabetes $(\mathrm{OR}=2,31 ; 95 \% \mathrm{CI}: 1,17-4,55) .{ }^{14}$ Medication adherence also play important fact $2 \mathrm{~s}$ in glycemic control, the previous study revealed those with high adherence to oral hypo-glycemic medications were less likely to have poor glycemic control $(\mathrm{OR}=0,54 ; 95 \% \mathrm{CI} ; 0,50-0,59) .{ }^{15,16}$

\section{CONCLUSIONS}

From 173 of 200 adult outpatient of health center were diabetes mellitus, $60 \%$ respondents of DM subjects had an uncontrollable blood glucose level and there was 
correlation between duration of diabetes, medication adherence, physical exercise level, type of physical exercise, duration of physical exercise and family supports with blood glucose level

Conflict of Interest: The author reports no conflicts of interest in this work.

Acknowledgement: All the authors thanks to Ministry of Research, Technology and Higher Education for research funding (grant number: 101-123/UN7.P4.3/ PP/2018). We also thanks to the Diponegoro University, study participant, Kedungmundu Health Center Semarang, for their cooperation in facilitating our study.

Ethical Clearence: Ethical clearance was obtained from Ethic Commission of Health Research, Faculty of Public Health UNDIP (094/EC/FKM/2018). All subjects signed informed consent to join the study.

\section{REFERENCES}

1. WHO. Diabetes The Problem. Diabetes Fact Sheet [Internet]. 2010;(February):2. Available from: http://www.who.int/nmh/publications/fact_sheet_ diabetes_en.pdf

2. Kemenkes RI. Situasi dan Analisis Diabetes. Pusat Data dan Informasi Kementerian Kesehatan RI. 2014. p. 2.

3. Dinas Kesehatan Kota Semarang. Profil Kesehatan Kota Semarang Tahun 2015. 2016.

4. Fowler MJ. Microvascular and Macrovascular Complications of Diabetes. 2011;29(3):116-22.

5. Stratton IM. Association of glycaemia with macrovascular and microvascular complications of type 2 diabetes (UKPDS 35): prospective observational study. Bmj [Internet]. 2000;321(7258):405-12. Available from: http:// www.bmj.com/cgi/doi/10.1136/bmj.321.7258.405

6. Del Prato S, Felton AM, Munro N, Nesto R, Zimmet $\mathrm{P}$, Zinman B, et al. Improving glucose management: Ten steps to get more patients with type 2 diabetes to glycaemic goal. Int J Clin Pract. 2005;

7. Carolyne R, Mosha T, Nyaruhucha C. Risk Factors Associated with Elevated Blood Glucose Among Adults in Mwanza City, Tanzania *1.
$2015 ; 14(2): 90-100$.

8. Badedi M, Solan Y, Darraj H, Sabai A, Mahfouz 5. Alamodi S, et al. Factors Associated with Long-Term Control of Type 2 Diabetes Mellitus. J Diabetes Res. 2016;2016.

9. Silva EFF, Ferreira CMM, Pinho L de, Silva EFF, Ferreira CMM, Pinho L de. Risk factors 6. $\mathrm{d}$ complications in type 2 diabetes outpatients. Rev Assoc Med Bras [Internet]. 2017;63(7):62171 Available from: http://www.scielo.br/ scielo.php?script $=$ sci_arttext $\&$ pid $=$ S010442302017000700621\&lng=en\&tlng=en

10. 4arez DT, Sentell T, Tokumaru S, Goo R, Davis ${ }_{4} \mathrm{~V}$, Mau MM. Factors Associated With Poor 4 lycemic Control or Wide Glycemic Variability Among Diabetes Patients in Hawaii, 2006-2009. Prev Chronic Dis [Internet]. 2012;9:120065. Available from: http://www.cdc.gov/pcd/ issues/2012/12_0065.htm

11. Rasheed M, Islam N, Mahjabeen W. Original Article Factors Associated with Uncontrolled Type 2 Diabetes Mellitus. 2015;4(2):68-71.

12. Sigal RJ, Armstrong MJ, Colby P, Kenny GP, Plotnikoff RC, Reichert SM, et al. Physical activity and diabetes. Acta Biomed l'Ateneo Parm [Internet]. 2005;76(SUPPL. 3):85-8. Available from: http://dx.doi.org/10.1016/j.jcjd.2013.01.018

13. Suh S-H, Paik I-Y, Jacobs K. Regulation of blood glucose homeostasis during prolonged exercise. Mol Cells. 2007;

14. Strizich G, Kaplan RC, González HM, Daviglus ML, Giachello AL, Teng Y, et al. Glycemic control, cognitive function, and family support among middle-aged and older Hispanics with diabetes: The Hispanic Community Health Study/Study of Latinos. Diabetes Res Clin Pract. 2016;117:64-73.

15. Mosen DM, Glauber H, Stoneburner AB, Feldstein AC. Assessing the association between medication adherence and glycemic control. Am J Pharm Benefits. 2017;9(3):82-8.

16. Egede LE, Gebregziabher M, Echols C, Lynch CP. Longitudinal Effects of Medication Nonadherence on Glycemic Control. Ann Pharmacother. 2014; 
Factors Related to Blood Glucose levels among type II Diabetes Mellitus Patients (A Cross-sectional study in Kedungmundu Public Health Center, semarang)

ORIGINALITY REPORT

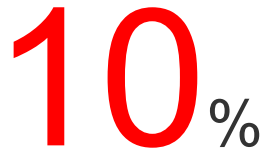

SIMILARITY INDEX

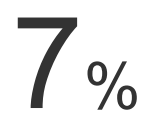

INTERNET SOURCES
$5 \%$

PUBLICATIONS
$2 \%$

STUDENT PAPERS

PRIMARY SOURCES

1 pt.slideshare.net

Internet Source

2 ajpblive.s3.amazonaws.com

Internet Source

3 www.marketresearch.com Internet Source

4 Appolinary Kamuhabwa, Emmanuel Charles.

"Predictors of poor glycemic control in type 2

diabetic patients attending public hospitals in

Dar es Salaam", Drug, Healthcare and Patient

Safety, 2014

Publication

5 www.opastonline.com

Internet Source

Submitted to University College London Student Paper 
8 connect.rtrn.net

9 repository.phb.ac.id Internet Source

10 www.dovepress.com Internet Source

11 Sukyung Cho, Haeun Jang, Kyong Park. "Trends in the management levels of metabolic risk factors in middle-aged and elderly patients with type 2 diabetes mellitus: The Korean National Health and Nutrition Examination Survey 1998-2014", PLOS ONE, 2017 Publication

"Principles of Diabetes Mellitus", Springer Nature, 2017 